\title{
Construction of Gender and National Identity in Turkey: Images of the First Lady in the Turkish Media (2002-7)
}

\section{Meral Ugur Cinar}

To cite this article: Meral Ugur Cinar (2014) Construction of Gender and National Identity in Turkey: Images of the First Lady in the Turkish Media (2002-7), Middle Eastern Studies, 50:3, 482-492, DOI: 10.1080/00263206.2014.886568

To link to this article: http://dx.doi.org/10.1080/00263206.2014.886568

Published online: 22 Apr 2014.

Submit your article to this journal ऍ

Џلll Article views: 522

Q View related articles $\square$

View Crossmark data ¿

Citing articles: 1 View citing articles $\square$ 


\title{
Construction of Gender and National Identity in Turkey: Images of the First Lady in the Turkish Media (2002-7)
}

\author{
MERAL UGUR CINAR*
}

Gender roles are dynamic constructs. These constructs are not only shaped by formally institutionalized gender inequalities but also informally such as through the media. The media is a prime example because it defines identities, establishes parameters of consensus, and relegates what is perceived as unconventional to the margins. ${ }^{1}$ Taking this into account, this article is concerned with the role media plays in constructing gender identities with a closer look at how depictions of First Ladies serve to perpetuate and contest dominant notions of gender and national identity in Turkey. This study is based on an analysis of the online content of two Turkish mainstream newspapers, Zaman and Hürriyet, between 18 November 2002 and 29 August $2007 .^{2}$ Zaman, currently the best-selling Turkish newspaper, is representative of an Islamist viewpoint and it is known to be close to the pro-Islamist Justice and Development Party (Adalet ve Kalkınma Partisi - AKP) government during the period covered in this article. ${ }^{3}$ Hürriyet is the biggest mainstream daily newspaper ${ }^{4}$ and has the most visited Turkish newspaper website. ${ }^{5}$ It belongs to Doğan Medya, Turkey's leading media and entertainment corporation. ${ }^{6}$

The selected time frame (18 November 2002-29 August 2007) includes immense changes in Turkish politics. It covers the first time a religious party, AKP, formed a single-party government in Turkey. ${ }^{7}$ The wives of most AKP parliamentarians and cabinet members (including Prime Minister Erdoğan's wife Emine Erdoğan) are veiled, which caused tension with secularist groups. Moreover, the presidential elections, which brought Abdullah Gül to office on 28 August 2007 and made Hayrünnisa Gül the first veiled president's wife in Turkey, were surrounded by debates regarding the appropriateness of a veiled First Lady in Turkey as well as broader debates on Islamism, secularism and the place of Turkey in the world. As we will see, not only current First Ladies, but also previous ones have been used as 'yardsticks' in these debates. Hence, all prime ministers' and presidents' wives are included in this study. ${ }^{8}$

Our analysis will reveal that despite their different worldviews, both Zaman and Hürriyet have striking similarities when it comes to gender roles. While both newspapers endorse female education and certain public roles for women, the agency of

* Department of Political Science and Public Administration, Bilkent University, Ankara, Turkey. E-mail: meral.ugur@gmail.com 
women in the public sphere is limited by the symbolic duties they are expected to perform, which are tied to the national image the newspapers deem fit for the country. Moreover, in both newspapers, First Ladies, as wives of politically powerful men, are expected to act primarily as domestic characters. Unlike the public sphere, where First Ladies mostly exist as symbols of national identity, they are assigned to the private sphere as their primary domain.

The role of media images of First Ladies is central to analysing how gender roles are shaped and perpetuated through the media, as First Ladies represent the characteristics of contemporary "womanhood', 'being both a "Lady" and the "First" one at that'. 'The lack of academic studies on Turkish First Ladies is hard to explain given the potential such studies hold. The Turkish case stands as a unique example among western and Middle Eastern countries. First, compared to many other Middle Eastern countries, Turkish nationalism has a different relationship to westernization. As Acar and Güneş-Ayata argue, perhaps due to the lack of a colonial history, Turkish nationalism lies in contrast to postcolonial nationalisms. Whereas in previously colonized countries gender reforms could be viewed as vestiges of the West, in the Turkish case, the image of the westernized woman became the keystone in creating the nation-state identity in Turkey. ${ }^{10}$

The Turkish case provides an interesting example when compared to other western countries as well. In her analysis of the role of women in nationalism projects, Anne McClintock argues that women 'are represented as the atavistic and authentic "body" of national tradition (inert, backward-looking, and natural) embodying nationalism's conservative principle of continuity'. ${ }^{11}$ While this might be true for many western countries, the Turkish case presents a more complex example of how gender hierarchies operate, as women played a crucial role in the early efforts of the founders of the Turkish Republic to break with the past and create a modern and western national identity. ${ }^{12}$ For instance, unlike their French predecessors, Turkish revolutionaries saw women's emancipation as central to Turkish nationalism, progress and civilization. ${ }^{13}$ The new regime also gave women important responsibilities in the modernization and secularization mission as it envisioned an ideal republican woman, whose body and practices needed to comply with the modern, secular, westernized vision. ${ }^{14}$ Hence, the role of women in the Turkish modernization project shows us a different picture than the one presented by McClintock where women are judged by the norm of preserving tradition.

The Turkish case also diverges from many western counterparts due to the specific role it assigns to women in the public sphere. Unlike the West, where the public sphere was originally a sphere reserved for men with property, the Turkish mode of modernization cherished women's public visibility. ${ }^{15}$ Women were granted equal rights of divorce, inheritance and child custody (1926); and the right to vote at local (1930) and national elections (1934). With the encouragement and endorsement of Atatürk, for example, his adopted daughters Sabiha Gőkçen and Ayşe Afetinan became the world's first female fighter pilot and the prime historian of Turkish official history, respectively. As Kandiyoti argues, Atatürk's choice to adopt daughters in a society where preference for male children was the norm carried a heavy symbolic significance. ${ }^{16}$

The unique situation of Turkey vis-à-vis the West, women's emancipation and religion makes it an interesting case to analyse in order to enhance our understanding of the interplay between media representations, nationalist projects and gender 
hierarchies. While the role of women in Turkey's modernization gives them unique opportunities, it also means that women's struggle in Turkey is fought on two different fronts: to break the confines of the domestic field as their primary domain and to gain agency as active citizens in the public sphere. The contestations from the 1980s onward between secularism and Islamism further complicated the picture as we will see from our analysis of Zaman and Hürriyet. Before we turn to our analysis, however, it is useful to make a brief introduction to the historical background of the tension between the secularists and Islamists, whose views are represented in Hürriyet and Zaman, respectively.

The last decades of the Ottoman Empire were a playground for westernism, modernism and Islam. With the new Republic (1923), pro-western and secularist ideals become dominant. The ruling elite switched to the Latin alphabet, western units of measurement and Sunday as the day of rest. In addition, the role of Islam in the public sphere was minimized: the Caliphate was abolished (1924), Islamic law repealed (1926) and Islam as the religion of the state revoked (1928). The state promoted a certain vision of Islam which suggested that religion is a matter of personal conscience and should not be expressed in the public sphere. Failing to act in this manner was considered reactionary and a sign of disloyalty to the new regime.

There was little political opposition to the secularist configuration in Turkey in the early decades of the Republic. This began to change in the 1980s as Islam became an 'effective and strong political, economic and cultural force'. ${ }^{17}$ Turkish society underwent tremendous transformation in this era particularly due to the neoliberal economic policies that integrated Turkey into the world economy. Expectations for freedom of enterprise also brought expectations for freedom of expression, which provided an opportunity for Islamic forces to legitimize their cause at the national level. ${ }^{18}$

Among demands for more rights to express religious identities, the headscarf gained prominence. Unlike male attire, which was regulated by the Hat Law (1925), there was no such nationwide regulation regarding female citizens in the early years of the Republic. Yet local administrations could enforce unveiling. In the 1980s, the headscarf ban became stricter as more veiled female students started to attend universities. In 1989, the Constitutional Court decided that wearing headscarves in public institutions is against secularism, which is an essential element of the regime. Attempts by the current AKP government to lift the headscarf ban were annulled by the Constitutional Court in 2008. ${ }^{19}$ The ban on wearing the headscarf in the civil service was lifted in September 2013. However, this excludes judges, prosecutors, the police and military personnel.

As newly assumed Islamic identities gained public visibility mainly through women's headscarves ${ }^{20}$ this public visibility upset the dominant notion that the public sphere should be free of religious symbols. Moreover, protests in favour of headscarves heightened the threat perceptions among secularists who saw headscarves as symbols of an alternative hegemonic political project and feared that 'their life-world may be encroached upon and threatened, ${ }^{21}$ Even though it is not as heightened as in the 2002-7 period, the tension around veiling still remains.

After a brief historical background, we will now turn to our analyses of images of the First Lady in Zaman and Hürriyet in relation to the debates on modernity and national identity in Turkey. 
In an atmosphere where the 'civilizational' premise of the ideal republican woman $^{22}$ is still central to the debates on Turkishness, First Ladies are under strict media scrutiny. Images of the First Lady are central for both those who support a secular and westernized country and those who envision a pro-Islamist societal order. It is noteworthy to see that one founding ideal of the republic is still alive not only in Hürriyet but also in Zaman. In both newspapers, public campaigns for female literacy led by Semra Sezer (the wife of the former president Ahmet Necdet Sezer (2000-2007)) and Emine Erdoğan are cited in detail. ${ }^{23}$

Hürriyet puts a lot more emphasis on women's education as a central credential for First Ladies; if First Ladies have received higher education, this does not go unnoticed. ${ }^{24}$ In addition to this, both newspapers cite the demands of First Ladies such as Emine Erdoğan, Semra Sezer and Hayrünnisa Gül for more women's rights. ${ }^{25}$ Yet the agreement between Zaman and Hürriyet on the public role of First Ladies seems to end here. Both newspapers enter into the struggle about Islam, secularism and nationhood through images of the First Lady. The focal points of this struggle are the attitudes, habits and clothing of First Ladies. Hürriyet depicts an ideal First Lady as someone who is modern and can compete in modernity and civilization with her western counterparts. Hürriyet shows how Turkish First Ladies internalized the values of modernization through their participation in public life. For example, Hürriyet writes that the greatest pleasure for Mevhibe Inönü was riding a horse with her husband Ismet Inőnü (second president of Turkey, 1938-50) and that she also liked to drive a car. ${ }^{26}$ The same piece also stresses the horse-riding theme in the case of Latife Uşakki, the wife of Ataturk, the founder of the Republic, from 29 January 1923 until their divorce on 5 August 1925.

Zaman, on the other hand, stresses the more religious aspects of First Ladies' lives. For instance, the columnist Mustafa Armağan says that Reşide Hanım (wife of the third president, Celal Bayar (1950-60)) always prayed five times a day. ${ }^{27}$ In addition to this, Zaman finds it newsworthy when First Ladies such as Semra Sezer and Rahşan Ecevit, ${ }^{28}$ who are not in fact veiled but on the contrary are wives of secularist politicians, cover their heads, for instance when they go into a mosque or to a funeral. $^{29}$

As the cornerstone of Turkish modernist transformation, ${ }^{30}$ clothing is at the centre of public debates and it constitutes the field in which the public images of First Ladies differ the most in Hürriyet and Zaman. One of the major debates revolves around the first Turkish First Lady, Latife Uşşaki, and whether she can be set as an example of a veiled woman for future First Ladies. To endorse such an idea, Zaman presents Gül's wife Hayrünnisa Gül as 'The second veiled First Lady', Latife Uşşaki being the first. ${ }^{31}$ Another piece in Zaman states that not only Latife Uşşaki, but also Mevhibe Inőnü and Reşide Bayar, were veiled. In this piece, the columnist Mustafa Armağan states that these women were only unveiled gradually. ${ }^{32}$ Another columnist, Nedim Hazer, also writes a piece endorsing the view that Latife Uşşaki was veiled and that this shows that the fact Hayrünnisa Gül is veiled is not a problem. ${ }^{33}$ In addition, the newspaper also devotes a lot of space to politicians and intellectuals who make similar points to the columnists. ${ }^{34}$

Hürriyet columnists, on the other hand, are furious about such allegations. They oppose it on various grounds. First of all, they say, the regulations on clothing were introduced after Ataturk and Uşşaki were divorced. ${ }^{35}$ Second, they say that the 
historical circumstances (the Ottoman legacy in society) led Uşşaki to cover her head in public. They also add that the headscarf did not cover all of Uşşaki's hair and she abandoned it altogether later on. ${ }^{36}$ The newspaper also cites an article from The Independent that contrasts Latife Uşşaki and Emine Erdoğan, showing their differences. ${ }^{37}$ Soner Yalçın even writes a hypothetical letter in the name of Latife Uşşaki where Uşşaki responds to Erdoğan. In this letter, Uşşaki states that her attire was modern compared to the times in which she lived. She also asks Tayyip Erdoğan if Hayrünnisa Gül would also be willing to act in the interest of the state on the headscarf issue and take her headscarf off for the good of the state. ${ }^{38}$

In the struggle over the place of the headscarf in the Turkish national identity and the debates over its legitimacy in the public sphere, the clothing of Emine Erdoğan and Hayrünnisa Gül are crucial. Politicians and bureaucrats, as well as many journalists, columnists and fashion designers, take part in this debate, to which the media gives high publicity. In this regard, the clothing of Emine Erdoğan and, back then, the president's wife Semra Sezer are often juxtaposed in Hürriyet. In one of these pieces, the clothing of Emine Erdoğan is described in detail, including her headscarf, without praising any element of it, while in the same piece Semra Sezer is praised for her elegance. ${ }^{39}$

More explicitly, Hürriyet columnists severely criticize Emine Erdoğan for her clothing and more directly for the headscarf she is wearing. ${ }^{40}$ Yalçın Bayer in Hürriyet claims that because of the way she dresses, Emine Erdoğan creates a 'dowdy Turkey' image and her clothing provides evidence of AKP's reluctance to modernize. ${ }^{41}$ One female colmunist writes that Emine Erdoğan needs to get advice from 'fashion designers who face the West' concluding with the statement that 'because we are women, we need to put more effort'. ${ }^{42}$

First Ladies are seen to represent national identity, not only for an internal but also for an external audience. In this respect, every meeting at the international level that is attended by Emine Erdoğan and Hayrünnisa Gül is a source of bitterness and anger for the columnists of Hürriyet. Erdoğan and Gül's clothing are juxtaposed to people such as the Swedish Queen, Syrian, Jordanian, Pakistani Malaysian, Azerbaijani and Turkish-Cypriot First Ladies. ${ }^{43}$ The authors are concerned with the international image of the country and they see this picture as a threat to secularism. Authors such as Türenç and Çölaşan find the contrast between Gül and Erdoğan's clothing and other Muslim country First Ladies' clothing especially insulting. Comparing Arab countries to Turkey, the secularist opinion leaders express their bitterness when they see images where Turkey looks more 'backward' than these countries. Due to the belief that modernization and democracy are only possible through the secularization of the public sphere, Erdoğan's attire is not only seen harmful to the image of Turkey as a secular country, but also as a modern and democratic one. The columnists find that as the vanguard country of modernization and women's emancipation in the Muslim world, Turkey deserves better. ${ }^{44}$

It is worth noting, however, that the secularist view does not suggest that any style of clothing on the condition that women are unveiled is welcome. In line with Kandiyoti's claim that 'the management of femininity and sexual modesty became part and parcel of the symbolic armour of the "modern" woman', ${ }^{45}$ First Ladies are expected to dress in such a way that they reflect a modern Turkey that has cut its ties with the past but within the limits of sexual modesty: Reşide Bayar and Mevhibe 
Inőnü are noted for wearing modest clothes ${ }^{46}$ and Semra Sezer to have said that she does not dye her hair, does not wear jewellery, prefers unadorned clothing and has no adherence to brand names. ${ }^{47}$

Those who do not support the image of women envisioned by the founding elite and embraced by the majority of the country but who instead want to create an alternative image of women in Turkey, and an alternative image of Turkey in general, see a new opportunity in First Ladies such as Gül and Erdoğan. In contrast to the negative depictions of veiled First Ladies' interactions in the international arena, Zaman frames their interactions positively and praises the First Ladies for their stylishness during these visits. It tells its readers, for instance, how admired Emine Erdoğan was in Pakistan and how her elegance was praised. ${ }^{48}$ It also points out that Emine Erdoğan was as fashionable as Queen Raina ${ }^{49}$ and elaborates on the warm welcome Emine Erdoğan received from the Bush family. ${ }^{50}$

Fashion designers join the debate as authoritative voices in defining what normal or proper attire for a woman representing Turkey would look like aesthetically. The issue of whether Hayrünnisa Gül will receive professional help from designers such as Atıl Kutoğlu in order to 'modernize' her headscarf preoccupied Hürriyet for a long time. ${ }^{51}$ Similarly, Hürriyet reported that many fashion designers did not like Emine Erdoğan's style and published suggestions by designers on how to improve it. These suggestions were primarily concerned with how to modernize her headscarf. ${ }^{52}$

Zaman, on the other hand, praises Hayrünnisa Gül's fashion tastes and states that her fashion and makeup styles are admired by fashion designers. ${ }^{53}$ Zaman also cites two fashion designers, Neslihan Yargıcı and Faruk Saraç, who criticize other designers' views on 'modernizing' Gül's headscarf. ${ }^{54}$ Another piece in Zaman, written by a fashion designer, Reyhan Yazıc1, picks Gül as the most fashionable First Lady. ${ }^{55}$

Within the debate on First Ladies' headscarves, columnists at Hürriyet do not shy away from demanding that Hayrünnisa Gül uncover her head or at least cover it in a more 'modern' way (meaning, leave some of it open) ${ }^{56}$ and they invite her husband to convince her to do so. ${ }^{57}$ The only critical voices on such interference in First Ladies' attire come from columnists Ahmet Hakan of Hürriyet and Nihal Bengisu Karaca of Zaman. Ahmet Hakan wrote a series of pieces in Hürriyet criticizing those who think that Tayyip Erdoğan should urge his wife to remove her headscarf. Hakan states that it is wrong to assume that it is Emine Erdogan's responsibility to remove her headscarf so that her husband can get into office. He adds that it is disrespectful not only to Emine Erdoğan but also to all women to say that 'Tayyip Erdoğan needs to urge his wife to remove the headscarf'. It is also a sign of male oppression which we should not approve. ${ }^{58}$ Hakan criticizes both the Islamists and the secularists for failing to appreciate that women have an identity separate from their husbands. ${ }^{59}$ In parallel with this, in her column in Zaman, Karaca criticizes the attitude of the two different camps towards First Ladies. First, she criticizes radical Islamist notions that try to exclude more moderate approaches to veiling. Second, she criticizes the exclusionary attitudes of some secularist sectors towards these First Ladies. She finishes her piece by saying: 'God may help those scouts who are left outside the camps. ${ }^{60}$ These two columnists' voices remain very marginal compared to the overall tone of the newspapers.

Zaman and Hürriyet's images of the First Lady demonstrate that Çınar's claim that secularist and Islamist politicians have used the female body to promote their 
own national project at the expense of women's agency applies equally to the way the media takes part in the secularist-Islamist struggle. ${ }^{61}$

Zaman and Hürriyet's images of the First Lady have significant implications for the relationship between the media and beauty norms. Bartky argues that normative femininity is centred on the woman's body; its sexuality and its appearance, ${ }^{62}$ and Gill maintains that women who do not conform to the media's requirements that they be 'eye candy' are subjected to vilification. ${ }^{63}$ While both Gill's and Bartky's points are true, it is worth taking into account that attractiveness is not a universal concept and the discourse surrounding it is not only culturally but also politically specific. As this section has shown, beauty norms and gender expectations are tightly bound with national imaginaries and meanings attached to words such as dowdy, ugly and chic are both culturally and politically significant.

The Turkish Republic was one of the first states to extensively address the question of women's emancipation and grant women equal rights on many public matters, improving the status of women in society and expanding their political rights. However, it did not alter the primarily domestic definition of the female role in Turkish society. ${ }^{64}$ For instance, until 2002 the Civil Code designated the husband as the head of the family, allowed the husband to choose the place of residence for the family, and prioritized the father's decision over custody in cases of divorce. ${ }^{65}$ Even today, women need to take their husbands' surnames. ${ }^{66}$ Moreover, a woman's record in the population register is carried over and placed under her husband's family register after marriage. ${ }^{67}$ As a result of this forced change in surname and population registry through marriage, the official records and genealogy of the woman are uprooted and she is literally transferred to the family of her husband.

As we shall see below, media images in Zaman and Hürriyet reinforce the notion that the private sphere is the primary field designated for women and they keep gender inequality intact. Both newspapers uncritically promote depictions of First Ladies that emphasize their domestic features and show them as willingly embracing this domestic role together with the gender hierarchy it embodies. In this context, the household duties of the First Ladies are brought to the fore. For example, regarding Melahat Gürsel, ${ }^{68}$ Hürriyet states that she defined herself primarily as a cook, among other things, and that she preferred to do the cooking herself and sewing was her favourite activity. ${ }^{69}$ Similarly, Zaman elaborates on the details of the teas Emine Erdoğan prepares for her husband, ${ }^{70}$ while at the same time stating that Rahsan Ecevit runs the kitchen at home. ${ }^{71}$ The most recent example is Zaman's praise of Hayrünnisa Gül as the person who does the domestic work, goes shopping for the kitchen and likes to cook her husband's favourite dishes. ${ }^{72}$

Through media depictions, the First Lady's duties reach such a point that sacrificing her life to those of her husband and her children is normalized. Both newspapers highlight their patience, their fondness and unconditional support for their husbands. This is the case for Mevhibe Inő nü, ${ }^{73}$ Reşide Bayar, ${ }^{74}$ Nermin Erbakan ${ }^{75}$ and Hayrünnisa Gül. ${ }^{76}$

The devotion and sacrifices of First Ladies are not pictured as part of a relationship based on love and mutual support of two equals but rather affirm the patriarchal conception of femininity and patriarchal subjection of women to men. ${ }^{77}$ Lemish and Drob state that regarding Israeli First Ladies, 'the more devotion and 
self-sacrifice exhibited by the woman in relieving her husband of any responsibility in the private sphere the better she is portrayed by the media'. ${ }^{78}$ This point also applies to the Turkish case. Yet media depictions are not only about the roles of these women as First Ladies and they are not only functional in the sense that they make sure that the president or prime minister can do his job properly. They go beyond the husband's term of office and relate to the lives of the women and to Turkish womanhood at large. The fact that the information about the First Ladies cited above is mostly given in biographical pieces illustrates this point. These characteristics - devotion to the husband, self-sacrifice and performing domestic duties - are deemed as such important parts of the lives of these women that they have to be mentioned in their life stories. In other words, these are characteristics that make them what they are, regardless of their husbands' terms of office.

As expected, the primarily domestic role of the First Ladies significantly limits their place in the public realm as active citizens, in which they can exist only under certain conditions. Zaman's praise of Hayrünnisa Gül for always smiling, not talking too much and chatting briefly with political journalists, while refraining from talking about politics, is telling in this regard. ${ }^{79}$ While voluntary work in charity organizations is viewed in a positive light, ${ }^{80}$ First Ladies are discouraged from taking part in active politics. Criticism of Rahşan Ecevit can be seen as an example of this. Any time she played an important role in the decision-making process of the party which she was in fact eligible to do as she was also a high-ranking party member - it was seen as the weakening of her husband's power and a deviation from proper politics. ${ }^{81}$ A similar situation is valid for Semra Özal, whose political manoeuvres were viewed as harmful to her husband's image and to Turkish politics more generally. ${ }^{82}$

This attitude towards First Ladies should not be seen as denial of access to the public realm and to politics for women. Since the sociopolitical framework gave legitimacy to the presence of women in the public space as asexualized and defeminized subjects fully devoted to the nation's progress, ${ }^{83}$ the feminine characteristics which accompany their role prevented First Ladies from being seen as politically active individuals. As Caha argues, women who were encouraged to take part in public affairs managed to do so only after they left their 'femininity' in the private realm. ${ }^{84}$ Golle identifies these women as the masculine girls of republican fathers. ${ }^{85}$ This supports Pateman's claim that there are two ways of existing in the public realm for women. Either they are the subordinate feminine figure who reproduces the patriarchal discourse, or they 'must disavow [their] bodies and act as part of the brotherhood'. 86

The depictions of First Ladies in Hürriyet and Zaman justify the feminist criticism of media portrayals on the ground that they fixate the gendered separation between the public sphere of men that is open, rational and political and the closed, emotional and care-giving world of women. ${ }^{87}$ It is striking to see that newspapers as diverse as Hürriyet and Zaman, one secularist and one Islamist, both perpetuate the domestic image of First Ladies and the masculine definition of the public sphere.

This article takes a snapshot of female representations in the Turkish media from 2002 to 2007. It suggests that while there is a struggle between the secularist and Islamist media on issues such as Turkish national identity and public visibility, Islamists and secularist camps are not using polar opposite discourses as far as 
gender representations are concerned. While the Islamists question the parameters of the nation and the public sphere, the gender boundaries remain intact. Both sides emphasize and normalize the domestic roles of women. In their public roles, women are assigned a more symbolic role as the objects of the political struggle in defining the national image and the nature of the political regime. This shows us how deep the assumptions on gender roles run, to the extent that they are accepted by both camps. The conclusion reached by this article should be taken as a call for awareness to the media regarding the limitations of its gender discourse. It should also be seen as a reminder that those who want to advocate women's emancipation need to rethink their arguments so as to let the women speak for themselves in all spheres of life.

\section{Notes}

1. D. Lemish, 'Normalizing Inequality: Portrayals of Women in the Israeli Media', Journal of Israeli History, Vol.21, No.1 (2002), p.110.

2. Online archives of Hürriyet and Zaman can be found on http://hurarsiv.hurriyet.com.tr/arsiv/ and http://www.zaman.com.tr/ara.do?method=search.

3. Open Source Center, 'Turkey: Guide to Major Turkish Daily Newspapers', http://www.fas.org/irp/ dni/osc/turkish-news.pdf, 7 Oct. 2008, p.24.

4. I. Çetin, 'Veiled Representations. Political Battles around Female Sexuality in Turkish Print Media', Feminist Media Studies, Vol.10, No.4 (2010), p.413.

5. Alexa, 'The Top 500 Sites in Turkey', http://www.alexa.com/topsites/countries/TR (accessed 3 April 2011).

6. Open Source Centre, 'Turkey: Guide to Major Turkish Daily Newspapers', p.5.

7. Within the AKP, Abdullah Gül was replaced as prime minister by Tayyip Erdoğan on 14 March 2003.

8. Since the concept of 'First Lady' in Turkey is used interchangeably for the wife of both the president and the prime minister, I will also make no distinction and use the term for both of them.

9. D. Lemish and G. Drob, 'All the Time His Wife: Portrayals of First Ladies in the Israeli Press', Parliamentary Affairs, Vol.55, No.1 (2002), p.129.

10. F. Acar and A. Güneş-Ayata (eds.), Gender and Identity Construction (Leiden: Brill, 2000), p.338.

11. A. McClintock, 'Family Feuds: Gender, Nationalism and the Family', Feminist Review, Vol.44 (1993), p.66.

12. N. Göle, 'The Gendered Nature of the Public Sphere', Public Culture, Vol.10 (1997), p.61; D. Kandiyoti, 'End of Empire: Islam, Nationalism, and Women in Turkey', in D. Kandiyoti (ed.), Women, Islam, and the State (Basingstoke: Macmillan, 1991), p.41.

13. V. Moghadam, Modernizing Women: Gender and Social Change in the Middle East (Boulder, CO: Lynne Rienner, 1993), p.81.

14. B. Gökariksel and K. Mitchell, 'Veiling, Secularism, and the Neoliberal Subject: National Narratives and Supranational Desires in Turkey and France', Global Networks, Vol.5, No.2 (2005), p.155; Y. Arat, 'The Project of Modernity and Women in Turkey', in S. Bozdoğan and R. Kasaba (eds.), Rethinking Modernity and National Identity in Turkey (Seattle: University of Washington Press, 1997); A. Durakbaşa, 'Cumhuriyet Döneminde Modern Kadın ve Erkek Kimliklerinin Oluşumu: Kemalist Kadin Kimliği ve "Münevver Erkekler", in A.B. Hacımirzaoğlu (ed.), 75 Yllda Kadınlar ve Erkekler (Istanbul: Tarih Vakfi Yayınları, 1998); D. Kandiyoti, 'Gendering the Modern: On Missing Dimensions in the Study of Turkish Modernity', in Bozdoğan and Kasaba (eds.), Rethinking Modernity and National Identity in Turkey.

15. Göle, 'The Gendered Nature of the Public Sphere', pp.63-6.

16. Kandiyoti, 'Gendering the Modern', p.123.

17. F. Keyman, 'Modernity, Secularism and Islam: The Case of Turkey', Theory, Culture \& Society, Vol.24, No.2 (2007), p.223. 
18. A. Saktanber and G. Çorbacioğlu, 'Veiling and Headscarf-Skepticism in Turkey', Social Politics: International Studies in Gender, State \& Society, Vol.15, No.4 (2008), p.524.

19. Ibid., pp.514-15 and 519.

20. A. Çınar, Modernity, Islam, and Secularism in Turkey: Bodies, Places, and Time (Minneapolis: University of Minnesota Press, 2005), p.18.

21. Kandiyoti, 'Gendering the Modern', p.128.

22. J.B. White, 'State Feminism, Modernization, and the Turkish Republican Woman', NWSA Journal, Vol.15, No.3 (2003), p.157.

23. Zaman, 30 Dec. 2002, 25 Jan. 2003, 6 May 2004, 12 Oct. 2004, 11 March 2005, 2 June 2005, 17 May 2005, 4 Nov. 2006, 5 Nov. 2004, 6 Oct. 2004, 8 May 2005, 10 March 2005, 25 Feb. 2006; Hürriyet, 7 April 2007, 15 April 2007, 8 Nov. 2006, 7 Nov. 2006, 24 Nov. 2006, 17 May 2005, 28 June 2006, 10 Feb. 2005, 11 Feb. 2005, 14 Nov. 2006.

24. Hürriyet, 15 April 2007.

25. Hürriyet, 26 Nov. 2004, 10 Oct. 2004; Zaman, 28 March 2005, 8 March 2005; 9 March 2003, 27 March 2003.

26. Hürriyet, 15 April 2007.

27. M. Armağan, 'Başörtülü first lady'ler: Latife, Mevhibe, Reşide', Zaman, 19 Aug. 2007.

28. Rahşan Ecevit is the wife of Bülent Ecevit, prime minister 1974, 1977-79, 1999-2002.

29. Zaman, 2 Nov. 2006, 15 April 2005, 17 May 2003, 29 June 2004, 12 Nov. 2006.

30. White, 'State Feminism, Modernization, and the Turkish Republican Woman', p.149.

31. Zaman, 1 May 2007.

32. Armağan, 'Başörtülü first lady’ler', Zaman, 19 Aug. 2007.

33. M.N. Hazar, 'Resimlerdeki turban', Zaman, 6 July 2004.

34. Zaman, 10 Nov. 2005, 30 Nov. 2005, 23 May 2005.

35. Ö. Ince, 'Yarın Cumhuriyet', Hürriyet, 28 Oct. 2003; T. Türenç, 'Bu vahim yanlışı Başbakan bile yaptı', Hürriyet, 18 Aug. 2007; O. Ekşi, 'Erdoğan'a yakışmadı. .', Hürriyet, 17 Aug. 2007.

36. M.Y. Yılmaz, 'Önemli olan nasıl bağlandı̆̆ı değil', Hürriyet, 17 Aug. 2007; E. Çölaşan, 'Bak sen şu söyleyene!', Hürriyet, 2 June 2007.

37. Hürriyet, 2 July 2006.

38. S. Yalçın, 'Ilk Cumhurbaşkanlığı seçimi Atatürk'ü öldürüyordu!', Hürriyet, 19 Aug. 2007.

39. Hürriyet, 28 June 2004.

40. M.Y. Yılmaz, 'Danıştay’a saldırı bir filmde olsaydı', Hürriyet, 22 May 2006; E. Çapa, 'Gazamız mübarek olsun', Hürriyet, 24 Sept. 2004.

41. Y. Bayer, 'Rüküş Türkiye', Hürriyet, 16 May 2005.

42. A. Arman, 'Emine Erdoğan'ı bir başkası giydirmeli', Hürriyet, 10 May 2004.

43. Hürriyet, 14 June 2003; T. Türenç, 'Çelişkiler', Hürriyet, 25 Dec. 2004; T. Türenç, 'Demokratik rejime ayrı saflardan açılan ateş', Hürriyet, 2 June 2006; S. Devrim, 'Utanç Fotoğrafi', Hürriyet, 11 March 2007.

44. T. Türenç, 'Fotoğraftaki acı gerçekler ve Diğerleri...', Hürriyet, 19 March 2004; E. Çölaşan, '17 Ağustos'u unutmayalım', Hürriyet, 17 Aug. 2004.

45. Kandiyoti, 'Gendering the Modern', p.126.

46. Hürriyet, 15 April 2007.

47. Ibid.

48. Zaman, 18 June 2003.

49. Zaman, 26 Feb. 2006.

50. Zaman, 30 Jan. 2004.

51. Hürriyet, 27 July 2007, 16 Aug. 2007, 17 Aug. 2007, 18 Aug. 2007, 21 Aug. 2007.

52. Hürriyet, 25 Jan. 2003, 18 June 2003, 14 April 2007, 28 July 2007.

53. Zaman, 1 May 2007.

54. Zaman, 25 Aug. 2007.

55. R. Yazıcı, 'En şık "first lady" Hayrünnisa Gül', Zaman, 25 Aug. 2007.

56. C. Ülsever, 'Sözde değil özde democrat', Hürriyet, 1 Aug. 2007.

57. A.A. Bir, 'Merhaba', Hürriyet, 6 Jan. 2005.

58. A. Hakan, 'Gel Papa gel', Hürriyet, 26 Nov. 2006; A. Hakan, 'Dinle Paşa', Hürriyet, 24 Nov. 2006.

59. A. Hakan, 'Emine Hanım neden türbanını çıkarmamalı', Hürriyet, 5 Jan. 2006; A. Hakan, 'Ayıptır ayıp!', Hürriyet, 13 April 2006. 
60. N.B. Karaca, 'Formacılarla 'aç aç'çılar arasında: Başörtüsü', Zaman, 2 Feb. 2003.

61. Çınar, Modernity, Islam, and Secularism in Turkey, p.87.

62. S. Bartky, 'Foucault, Femininity, and the Modernization of Patriarchal Power', in Femininity and Domination (New York: Routledge, 1990).

63. R. Gill, Gender and the Media (Cambridge: Polity Press, 2007), p.116.

64. D. Kandiyoti, 'Emancipated but Unliberated? Reflections on the Turkish Case', Feminist Studies, Vol.13, No.2 (1987), pp.320, 324; D. Kandiyoti, 'Urban Change and Women's Roles: An Overview and Evaluation', in C. Kagitcibasi (ed.), Sex Roles, Family, and Community in Turkey (Bloomington: Indiana University Press, 1982), pp.101-20.

65. Medeni Kanun (Civil Code), 02/17/1926, Law No.743, Official Gazette No.339, 4 April 1926. The obligation for women to ask permission from her husband to be able to work was changed in 1990 as it was seen as unconstitutional by the Constitutional Court.

66. Turk Medeni Kanunu (Turkish Civil Code), 11/22/2001, Law No.4721, Official Gazette No.24607, 12 Aug. 2001. The law was put in effect 1 Jan. 2002. Before 1997, women only took their husband's surname and dropped their previous surname, but after amendment of the Civil Law, they can keep their surname if they want, yet they must also take their husband's surname in addition to theirs.

67. Nüfus Hizmetleri Kanunu (Law on Population Registration), 25 April 2006, Law No.5490, Official Gazette No.26153, 29 April 2006.

68. Melahat Gürsel is the wife of Cemal Gürsel, president 1961-66.

69. Hürriyet, 15 April 2007.

70. Zaman, 11 Dec. 2004.

71. Zaman, 25 June 2005.

72. Zaman, 21 Aug. 2007.

73. Hürriyet, 15 April 2007; Zaman, 25 March 2007.

74. Hürriyet, 15 April 2007.

75. Zaman, 25 Oct. 2005. Nermin Erbakan is the wife of Necmettin Erbakan, prime minister 1996-97.

76. Zaman, 21 Aug. 2007.

77. C. Pateman, 'The Fraternal Social Contract', in C. Pateman (ed.), The Disorder of Women: Democracy, Feminism and Political Theory (Palo Alto, CA: Stanford University Press, 1989), p.52.

78. Lemish and Drob, 'All the Time His Wife', p.136.

79. Zaman, 1 May 2007.

80. Zaman, 21 July 2004, 11 Feb. 2004, 29 Dec. 2002.

81. Zaman, 15 June 2003; M. Y1lmaz, "DSP" nin kader kurultayı ve "memur muhalefeti", Zaman, 25 July 2004; E. Çölaşan, 'Çocuk oyuncağı değil bu!', Hürriyet, 9 Sept. 2006.

82. Semra Özal is the wife of Turgut Özal, prime minister 1983-89, president 1989-93; Süsoy, 7 April 2003.

83. Gökariksel and Mitchell, 'Veiling, Secularism, and the Neoliberal Subject', p.155; A. Kadioğlu, 'Cinselliğin Inkarı: Büyük Toplumsal Projelerin Nesnesi Olarak Türk Kadınları', in Hacımirzaoğlu (ed.), 75 Yılda Kadınlar ve Erkekler, pp.89-100.

84. Ö. Çaha, 'The Ideological Transformation of the Public Sphere: The Case of Turkey', Alternatives: Turkish Journal of International Relations, Vol.4, No.1-2 (2005), p.19.

85. N. Gőle, Modern Mahrem: Medeniyet ve Örtünme (Istanbul: Metis, 1992), p.19.

86. Pateman, 'The Fraternal Social Contract', p.52.

87. Lemish, 'Normalizing Inequality', p.111. 